\title{
Prognostic value of lymph node ratio in laryngeal and hypopharyngeal squamous cell carcinoma: a systematic review and meta-analysis
}

Arikin Abdeyrim ${ }^{1{ }^{*}}$, Shizhi He ${ }^{2 \dagger}$, Yang Zhang ${ }^{3}$, Gulbostan Mamtali', Aibadla Asla ${ }^{1}$, Mirkamil Yusup ${ }^{1}$ and Jiang Liư ${ }^{4^{*}}$

\begin{abstract}
Background: Several recent studies have indicated that the lymph node ratio (LNR) is an independent prognostic factor for laryngeal and hypopharyngeal squamous cell carcinoma (LHSCC). The purpose of this paper is to assess the prognostic value of LNR and explore appropriate cutoff values by conducting a systematic review and metaanalysis.

Methods: Pubmed, Embase (via Ovid), and Cochrane library were systematically searched for studies on the prognostic value of LNR in LHSCC up to October 31, 2019. Then, Literature review, data extraction, and quality assessment of eligible studies were performed by two independent reviewers back-to-back. Lastly, Stata 14.0 software was hired to conduct a meta-analysis.
\end{abstract}

Results: A total of 445 articles were retrieved, and 13 studies published in English between 2013 and 2019 were included after the title/abstract and full-text screening. Among the 13 studies contributed to 4197 patients, seven studies were about hypopharyngeal squamous cell carcinoma (HPSCC), four studies about laryngeal squamous cell carcinoma (LSCC), and the remaining two studies about LHSCC. The meta-analysis results showed that shorter overall survival (OS) (HR 1.49; 95\%Cl: 1.18 to 1.88), disease-specific survival (DSS) (HR 1.66; 95\%Cl: 1.32 to 2.07) and disease-free survival (DFS) (HR 2.04; 95\%Cl: 1.54 to 2.71) were significantly correlated with a higher LNR in a random-effect model. The cutoff values of eligible studies were varied from 0.03 to 0.14 , and the lowest significant LNR was 0.044 .

Conclusion: LNR is a valuable prognostic factor in the survival of LHSCC and may be used to improve the tumor staging systems, which, however, requires the solid support of more high-quality studies.

Keywords: Hypopharyngeal cancer, Laryngeal cancer, Lymph node ratio, Prognosis, Meta-analysis

\footnotetext{
*Correspondence: arikiny@sina.com; jiangliusurgery@sina.com

Arikin Abdeyrim and Shizhi He have equally contributed to this work.

'Department of Otorhinolaryngology Head and Neck Surgery, People's

Hospital of Xinjiang Uygur Autonomous Region, 91 Tianchi Road, Tianshan,

Ürümqi, Xinjiang 830001, China

${ }^{4}$ Department of Neurosurgery, China-Japan Friendship Hospital, No. 2,

Yinghua East Street, Chaoyang District, Beijing 100029, China

Full list of author information is available at the end of the article
}

(C) The Author(s). 2020 Open Access This article is licensed under a Creative Commons Attribution 4.0 International License, which permits use, sharing, adaptation, distribution and reproduction in any medium or format, as long as you give appropriate credit to the original author(s) and the source, provide a link to the Creative Commons licence, and indicate if changes were made. The images or other third party material in this article are included in the article's Creative Commons licence, unless indicated otherwise in a credit line to the material. If material is not included in the article's Creative Commons licence and your intended use is not permitted by statutory regulation or exceeds the permitted use, you will need to obtain permission directly from the copyright holder. To view a copy of this licence, visit http://creativecommons.org/licenses/by/4.0/ The Creative Commons Public Domain Dedication waiver (http://creativecommons.org/publicdomain/zero/1.0/) applies to the data made available in this article, unless otherwise stated in a credit line to the data. 


\section{Introduction}

Treatment of laryngeal and hypopharyngeal cancer was frustrating due to its dysfunction and poor prognosis. Surgery is the standard treatment chemoradiotherapy alone has also shown efficacy in organ preservation trials, especially for advanced diseases [1]. However, some patients who have received surgery with adjuvant chemoradiotherapy after surgery, may still have a relapse. Therefore, it is of importance to improve outcomes via seeking valuable prognostic factors and identifying patients at high risk of recurrence.

Based on the tumor-node-metastasis (TNM) staging, the American Joint Committee on Cancer (AJCC) system [2] is the most commonly used staging system for laryngeal and hypopharyngeal cancers, which classified the status of lymph nodes of patients by their number, size, laterality, and extra nodal extension (ENE) [3]. Nevertheless, each factor's independent impact on clinical outcome remains unclear.

Lymph node ratio (LNR) or lymph node density (LND) is calculated as the number of positive lymph nodes divided by lymph node yield (LNY) removed through neck dissection [4]. Several studies showed that LNR could be employed as a supplement to the TNM staging system for better assessment of survival for esophageal [5], colorectal [6,7], gastric [8], and breast cancers [9]. In addition, two meta-analyses showed that LNR might be a significant prognostic indicator for head and neck malignancies [10] and oral [11] squamous cell carcinomas. Several recent studies [12-16] indicated that LNR was related to survival in patients with LHSCC, and reported on various cutoff points.

In this paper, a systematic review and meta-analysis were conducted to assess the prognostic value of LNR and explore appropriate cutoff values.

\section{Methods}

The study was conducted following the Preferred Reporting Items for Systematic Review and MetaAnalyses (PRISMA) guidelines [17].

\section{Search strategy}

We searched for the combination of free text words like "laryngeal," "larynx," "hypopharyngeal," "hypopharynx," "cancer?," "carcinoma?," "neoplasm?," "lymph nodes," "nodal," "ratio," and "density," in the PubMed, Embase (via Ovid), and Cochrane library systematically to find articles on the prognostic value of LNR in LHSCC up to October 31, 2019. Medical Subject Headings (MeSH) were adopted to in combination with the Boolean operators "AND" or "OR." The detailed retrieval strategy was shown in Tables S1, S2 and S3. Additionally, references cited in the articles were checked and found to be available.

\section{Study selection}

We had access to all published articles which evaluated the prognostic values of LNR in LHSCC, and included articles that were published in English, studied LHSCC patients with positive lymph nodes, reported calculated LND or LNR, clarified the LNR-related outcomes, and applied multivariate regression analysis to analyze the relationship between LNR and outcomes. As previous studies showed that no significant difference was noted between LSCC and HPSCC in LNR [18], we combined LSCC with LSCC for analysis.

We excluded studies whose full text were unavailable, as well as studies that were published as abstracts, reviews and case reports and not focused on the association between laryngeal or hypopharyngeal cancer and LNR. For studies that may overlap in the included population, we preferred the high-quality ones.

The literature selection was carried out by two researchers (AA and HSZ) independently, and any disagreement was resolved through negotiation or seeking the help of third party.

The outcomes were overall OS, DSS and DFS. OS was defined as the period from surgery to the last follow-up or death [19-22]. DSS was referred to the period from the initial diagnosis to LHSCC-related or treatment-related death [16, 20-22]. DFS was defined as the period from the surgery to the last follow-up with no evidence of recurrence or distant metastasis $[19,21,22]$.

\section{Data abstraction}

Two researchers (AA and HSZ) independently extracted the following information: author, year of publication, region, type of study, population basic characteristics, tumor basic characteristics, tumor treatment, follow-up time, and outcomes. If they did not reach a consensus over conflicting results, a third reviewer would participate making a decision.

\section{Quality assessment of eligible studies}

On referring to previously published meta-analyses [11, 23], we made the quality assessment of eligible studies based on the Reporting Recommendations for Tumor MARKer Prognostic Studies (REMARK) guidelines [24, 25]. The quality assessment covered the following eight domains: inclusion and exclusion criteria clarified, study design information, information of patient characteristics, information of tumor characteristics, LND or LNR measurements clarified, study outcomes defined clearly, follow-up time, and patient's attrition clarified.

Scores for each study ranged from 0 to 8 , with 8 representing the highest quality and 0 the lowest $[11,23]$. 


\section{Statistical analysis}

In order to assess the relationship between LNR and LHSCC, we calculated the pooled hazard ratio (HR) with a 95\% confidence interval (CI). The lowest LNR value was extracted for analysis, while the original articles presented two more categories. Based on the $95 \%$ CI not coming across the null line, HR greater than 1 indicated poor prognosis in LHSCC patients with a higher LNR value. If two more studies reported an outcome, we performed data synthesis in a random-effect model. Then, we applied the Cochran Q-static and $\mathrm{I}^{2}$ tests to estimate heterogeneity between studies [26], and a $P$-value of Qtest less than 0.05 or an $\mathrm{I}^{2}$ value higher than $50 \%$ indicated large heterogeneity between studies. Subsequently, the subgroup analysis and the meta-regression analysis were conducted to explore the sources of heterogeneity. The potential publication bias of eligible studies was identified using Funnel plots, the Begg's test, and the Egger's test. We considered a $p$-value of less than 0.05 statistically significant. The trim and fill method was applied to adjust the results of pooled analysis in the case of publication bias, and all statistical tests were two- sided. Statistical software Stata Version 14.0 (StataCorp, College Station, TX, 2014) was employed in the review.

\section{Results}

We retrieved 445 articles following the search strategy, among which 36 articles were eligible for the full-text screening process, and 13 articles [12-16, 18-22, 27-29] were included in the meta-analysis finally. Reasons for excluding studies in the full-text screening process were listed in Table S4. The PRISMA Flow diagram is shown in Fig. 1.

Among 13 articles contributed to 4197 patients (range, 46 to 1963; median, 105), seven studies were about HPSCC, four studies were about LSCC, and the remaining two studies were bout LHSCC. All studies were published in English between 2013 and 2019, with only one study contributed to 46 patients was designed as a prospective study, and the others as retrospective studies.

Seven $[13-16,21,22,29]$ and six studies [12, 18-20, 27, 28] were carried out in Eastern and Western, respectively. The mean or median follow-up time of

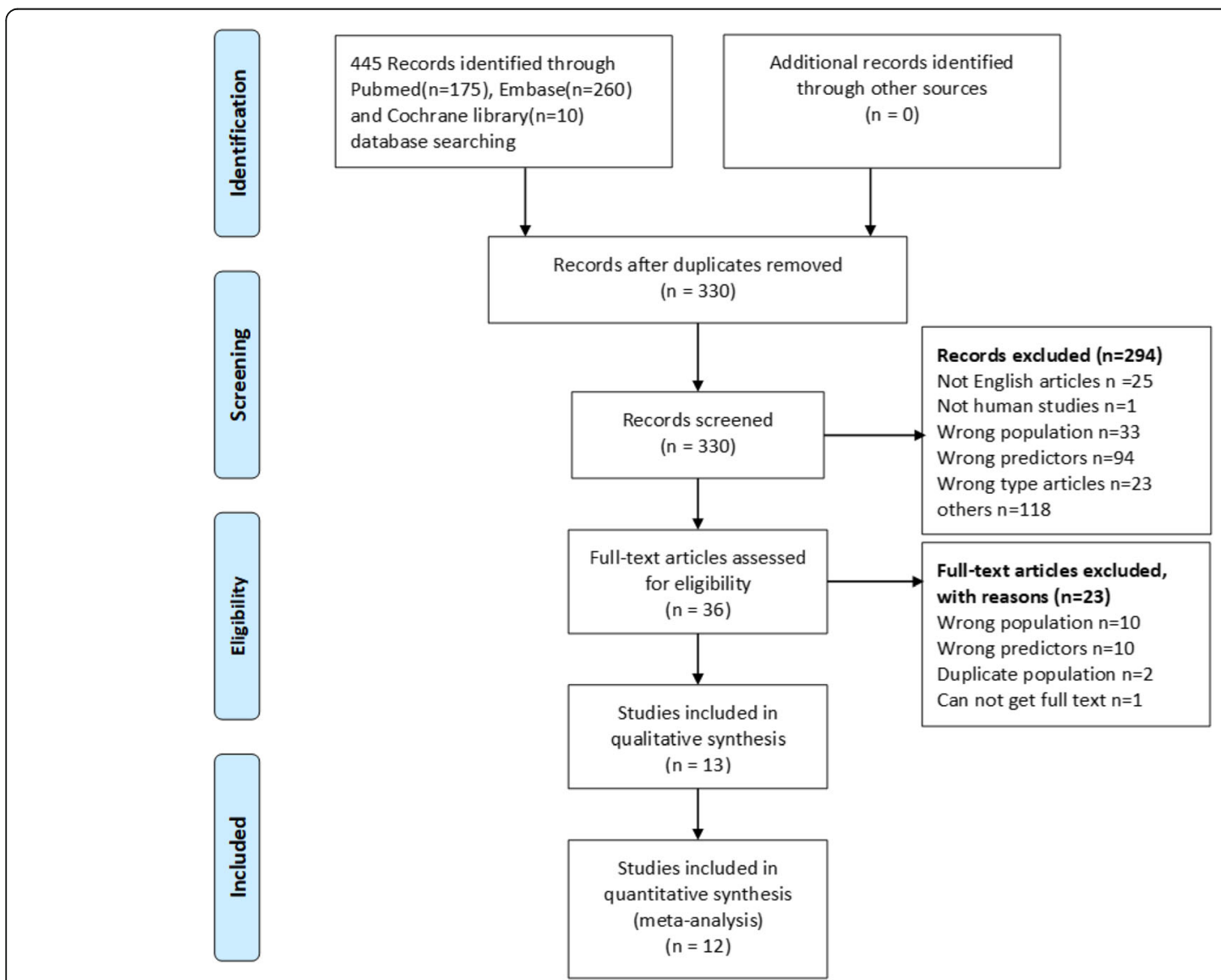

Fig. 1 PRISMA literature screening flow diagram. Preferred Reporting Items for Systematic Review and Meta-Analyses (PRISMA) literature screening flow diagram 
Table 1 Main characteristics of the eligible studies

\begin{tabular}{|c|c|c|c|c|c|c|c|c|c|}
\hline Study & Year & Region & $\begin{array}{l}\text { Study } \\
\text { period }\end{array}$ & $\begin{array}{l}\text { Type of } \\
\text { study }\end{array}$ & Population & $\begin{array}{l}\text { Endpoints } \\
\text { with HR }\end{array}$ & LNR cut-off & $\begin{array}{l}\text { Method of LNR } \\
\text { determination }\end{array}$ & $\begin{array}{l}\text { Follow-up time } \\
\text { (months) }\end{array}$ \\
\hline Ye [22] & 2018 & China & 2007 to 2016 & retrospective & HPSCC & OS, DFS & $<0.07, \geq 0.07$ & $\mathrm{ROC}$ & $\begin{array}{l}\text { Median } 33.1 \\
\text { (6.1 to } 110.7 \text { ) }\end{array}$ \\
\hline Lo [15] & 2017 & Taipei, China & 2001 to 2007 & retrospective & HPSCC & OS, DFS, DSS & $<0.113, \geq 0.113$ & Mean & $\begin{array}{l}\text { Mean } 51 \\
\text { (4 to } 144)\end{array}$ \\
\hline Suzuki [21] & 2016 & Japan & 2000 to 2015 & prospective & HPSCC & OS, DFS & $<0.09, \geq 0.09$ & Log-rank test & $\begin{array}{l}\text { Mean } \pm \text { SD } \\
45.7 \pm 40.6\end{array}$ \\
\hline Joo [14] & 2015 & Korea & 1993 to 2014 & retrospective & HPSCC & OS, DFS & $<0.055, \geq 0.055$ & $\mathrm{ROC}$ & $\begin{array}{l}\text { Mean } 37 \\
\text { (1 to } 151)\end{array}$ \\
\hline Hua [13] & 2015 & China & 2000 to 2005 & retrospective & HPSCC & OS & $<10,>10 \%$ & NA & $\begin{array}{l}\text { Median } 48 \\
\text { (12 to } 127)\end{array}$ \\
\hline Yu [29] & 2013 & China & 1965 to 2008 & retrospective & HPSCC & OS, DFS, DSS & $\leq 0.14,>0.14$ & LNR quartiles & $\begin{array}{l}\text { Mean } 41.8 \\
\text { (1 to } 295)\end{array}$ \\
\hline Wang [27] & 2013 & SEER & 1988 to 2008 & retrospective & HPSCC & OS, DFS & $\begin{array}{l}0-0.05,0.05-0.30 \\
>0.30\end{array}$ & Log-rank test & $\begin{array}{l}\text { Median } 23 \\
\text { (0 to } 238 \text { ) }\end{array}$ \\
\hline Imre [19] & 2016 & Turkey & 2006 to 2014 & retrospective & LSCC & OS, DFS & $<0.09, \geq 0.09$ & $\begin{array}{l}\text { Univariate } \\
\text { Cox analysis }\end{array}$ & $\begin{array}{l}\text { Mean } 33.5 \\
\text { (6 to } 94)\end{array}$ \\
\hline Ryu [16] & 2015 & Korea & 2001 to 2010 & retrospective & LSCC & DFS & $\leq 0.044,>0.044$ & $\mathrm{ROC}$ & $\begin{array}{l}\text { Median } 53.2 \\
\text { (2.1 to } 147.1 \text { ) }\end{array}$ \\
\hline Wang [28] & 2014 & SEER & 1988 to 2008 & retrospective & LSCC & OS, DFS & $\begin{array}{l}0-0.09,0.09-0.20 \\
>0.20\end{array}$ & Log-rank test & NA \\
\hline Künzel [20] & 2015 & Germany & 1980 to 2010 & retrospective & LSCC & DFS & $\begin{array}{l}<0.09,>0.09 /<0.09 \\
>0.09\end{array}$ & $\mathrm{ROC}$ & $\begin{array}{l}\text { Mean } 53 \\
\text { (0.1 to 229) }\end{array}$ \\
\hline Choi [12] & 2019 & Germany & 2006 to 2016 & retrospective & $\begin{array}{l}\text { HPSCC/ } \\
\text { LSCC }\end{array}$ & OS, DFS, DSS & 0.03 & $\mathrm{ROC}$ & $\begin{array}{l}\text { Median } 60 \\
\text { (24 to } 134 \text { ) }\end{array}$ \\
\hline Grasl [18] & 2019 & Austria & 1994 to 2018 & retrospective & $\begin{array}{l}\text { HPSCC/ } \\
\text { LSCC }\end{array}$ & OS, DFS, DSS & $\leq 0.07,>0.07$ & $\mathrm{ROC}$ & $\begin{array}{l}\text { Mean } \pm \text { SD } \\
55.6 \pm 59.3\end{array}$ \\
\hline
\end{tabular}

HPSCC hypopharyngeal squamous cell carcinoma, LSCC laryngeal squamous cell carcinoma, OS overall survival, DSS disease-specific survival, DFS disease-free survival, $R O C$ receiver operating characteristic; NA: not available

included studies, median or mean lymph node yield, and median or mean number of positive lymph nodes range from 23 to 60 months, 20 to 60 , and 1 to 4 , respectively. The cutoff values of LNR calculated by different methods in eligible studies varied from 0.03 to 0.14 , and the lowest significant LNR reported was 0.044. The basic features of the included studies, characteristics of patients and tumors are summarized in Tables 1 and 2.

The results of the quality assessment ranged from 4 to 7 (Table 3). Quality scores of 8 studies [14, 16, 18-22, 27] were more than 5 , indicating that most of the studies were moderate quality.

\section{Meta-analysis results}

Among the 13 eligible studies, 12 studies [12-15, 18-22, 27-29], 12 studies [12, 14-16, 18-22, 27-29] and 4 studies [12, 15, 18, 29] explored the association between LNR and OS, DSS, DFS outcomes respectively. The pooled analysis of studies reported LNR as the categorical variable showed the higher LNR values were associated with short OS (HR 1.85, 95\%CI 1.47 to 2.32, 9 studies) in the random-effect model $\left(\mathrm{I}^{2}=58.4 \%\right.$ ) (Fig. 2), short DSS (HR 1.99, 95\%CI 1.60 to $2.48,11$ studies) in the random-effect model $\left(\mathrm{I}^{2}=49.0 \%\right)$ (Fig. 3) and poor DFS (HR 2.04, 95\%CI 1.54 to $2.71,3$ studies) in the fixed-effect model $\left(\mathrm{I}^{2}=0.0 \%\right.$ ) (Fig. 4).

In addition, the meta-analysis results of studies [13, $27,28]$ reported LNR as continuous variable showed that higher LNR values indicated poor OS (HR 1.88, 95\%CI 1.63 to 2.17 ) and poor DSS (HR 2.33, 95\%CI 1.97 to 2.74 ) in the fixed-effect model $\left(\mathrm{I}^{2}=0.0 \%\right)$ (Fig. 3). Besides, one of the 13 studies [12] could not be quantitatively synthesized with other studies because its adjusted HR was unavailable. The univariate analysis suggested that LNR was a significant factor for OS, DSS and DFS outcomes $(P<0.05)$, while the multivariate analysis results did not favor LNR as an independent factor for OS, DSS and DFS outcomes.

The meta-regression analysis was carried out for OS outcome, but we were not able to identify factors that might affect inter-study heterogeneity. Besides, we conducted the subgroup meta-analysis to explore the sources of heterogeneity in OS outcome, but then when the studies divided into three subgroups by regions, the inter-study heterogeneity disappeared. Similarity, the pooled results suggested that high LNR were associated 
Table 2 Patient and tumor characteristics of eligible studies

\begin{tabular}{|c|c|c|c|c|c|c|c|c|c|c|}
\hline Author & Sample & Age & Male & Treatment & $\begin{array}{l}\text { Type of Neck } \\
\text { Dissection }\end{array}$ & $\begin{array}{l}\mathrm{T} \\
\text { stage }\end{array}$ & $\mathrm{N}$ stage & Subsite & LNY & $\mathrm{PN}+$ \\
\hline Ye [22] & 93 & $\begin{array}{l}\text { Mean } \\
56.9(32 \\
\text { to } 87)\end{array}$ & $98 \%$ & $\begin{array}{l}\text { Surgery OR Surgery } \\
\text { with (RT OR CRT) }\end{array}$ & $\begin{array}{l}\text { Radical, } \\
\text { Elective }\end{array}$ & $\begin{array}{l}\text { T1 to } \\
\text { T4 }\end{array}$ & $\begin{array}{l}\text { N0, N1, } \\
\text { N2a/b/c, } \\
\text { N3 }\end{array}$ & $\begin{array}{l}\text { Pyriform sinus, Posterior wall, } \\
\text { Postcricoid region, }\end{array}$ & NA & $\begin{array}{l}\text { Mean } 3 \\
(0 \text { to } \\
34)\end{array}$ \\
\hline Lo [15] & 120 & $\begin{array}{l}\text { Mean } \\
56(35 \\
\text { to } 89)\end{array}$ & $98 \%$ & $\begin{array}{l}\text { Surgery OR Surgery } \\
\text { with (RT OR CRT) }\end{array}$ & $\begin{array}{l}\text { Bilateral, } \\
\text { Unilateral }\end{array}$ & $\begin{array}{l}\text { T1 to } \\
\text { T4 }\end{array}$ & $\begin{array}{l}\text { N0, N1, } \\
\text { N2a/b/c, } \\
\text { N3 }\end{array}$ & $\begin{array}{l}\text { Pyriform sinus, Posterior } \\
\text { pharyngeal wall, Postcricoid }\end{array}$ & NA & Mean 4 \\
\hline $\begin{array}{l}\text { Suzuki } \\
{[21]}\end{array}$ & 46 & $\begin{array}{l}\text { Median } \\
66\end{array}$ & $94 \%$ & $\begin{array}{l}\text { Surgery OR Surgery } \\
\text { with (RT OR CT OR } \\
\text { CRT) }\end{array}$ & $\begin{array}{l}\text { Extended } \\
\text { radical, } \\
\text { Modified } \\
\text { Radical, } \\
\text { Selective }\end{array}$ & $\begin{array}{l}\text { T1 to } \\
\text { T4 }\end{array}$ & $\mathrm{N} 1, \mathrm{~N} 2$ & Priform sinus, Others & $\begin{array}{l}\text { Median } \\
59.5(14 \\
\text { to } 114)\end{array}$ & $\begin{array}{l}\text { Median } \\
3(1 \text { to } \\
15)\end{array}$ \\
\hline $\begin{array}{l}\text { JoO } \\
{[14]}\end{array}$ & 105 & $\begin{array}{l}\text { Mean } \\
61(35 \\
\text { to } 80)\end{array}$ & $97 \%$ & $\begin{array}{l}\text { Surgery OR Surgery } \\
\text { with (RT OR CRT) }\end{array}$ & $\begin{array}{l}\text { Bilateral, } \\
\text { Modified } \\
\text { Radical, } \\
\text { Radical, } \\
\text { Selective }\end{array}$ & $\begin{array}{l}\text { T1 to } \\
\text { T4 }\end{array}$ & $\begin{array}{l}\text { N1 to } \\
\text { N3 }\end{array}$ & $\begin{array}{l}\text { Pyriform sinus, Posterior } \\
\text { pharyngeal wall, Postcricoid } \\
\text { region }\end{array}$ & $\begin{array}{l}\text { Median } \\
54(15 \text { to } \\
176)\end{array}$ & $\begin{array}{l}\text { Median } \\
3(1 \text { to } \\
31)\end{array}$ \\
\hline $\begin{array}{l}\text { Hua } \\
{[13]}\end{array}$ & 81 & $\begin{array}{l}\text { Median } \\
60(36 \\
\text { to } 80)\end{array}$ & $98 \%$ & $\begin{array}{l}\text { Surgery OR Surgery } \\
\text { with (RT OR CRT) }\end{array}$ & $\begin{array}{l}\text { Bilateral, } \\
\text { Unilateral }\end{array}$ & $\begin{array}{l}\text { T1 to } \\
\text { T4 }\end{array}$ & $\begin{array}{l}\text { N1 to } \\
\text { N3 }\end{array}$ & $\begin{array}{l}\text { Pyriform sinus, Posterior wall, } \\
\text { Postcricoid region }\end{array}$ & $\begin{array}{l}\text { Median } \\
47 \text { (3 to } \\
95)\end{array}$ & $\begin{array}{l}\text { Median } \\
2(0 \text { to } \\
17)\end{array}$ \\
\hline Yu [29] & 279 & $\begin{array}{l}\text { Mean } \\
57.8(34 \\
\text { to } 85)\end{array}$ & $93 \%$ & $\begin{array}{l}\text { RT OR RT with (CRT } \\
\text { OR ICT OR Surgery } \\
\text { OR Surgery with CT) }\end{array}$ & $\begin{array}{l}\text { Radical, } \\
\text { Modified } \\
\text { Radical, } \\
\text { Selective }\end{array}$ & $\begin{array}{l}\text { T1 to } \\
\text { T4 }\end{array}$ & $\begin{array}{l}\text { N0 to } \\
\text { N3 }\end{array}$ & $\begin{array}{l}\text { Pyriform sinus, Posterior wall, } \\
\text { Postcricoid region }\end{array}$ & $\begin{array}{l}\text { Median } \\
20(2 \text { to } \\
76)\end{array}$ & $\begin{array}{l}\text { Median } \\
2.0(0.5 \\
\text { to } 22.0)\end{array}$ \\
\hline $\begin{array}{l}\text { Wang } \\
{[27]}\end{array}$ & 916 & $\begin{array}{l}\text { Median } \\
61(35 \\
\text { to } 93)\end{array}$ & $42 \%$ & $\begin{array}{l}\text { Surgery OR Surgery } \\
\text { with RT }\end{array}$ & NA & $\begin{array}{l}\mathrm{T} 1 \text { to } \\
\mathrm{T} 4 \mathrm{a} / \\
\mathrm{b}, \mathrm{Tx}\end{array}$ & $\begin{array}{l}\text { N1 to } \\
\text { N3 }\end{array}$ & $\begin{array}{l}\text { Pyriform sinus, Posterior wall, } \\
\text { Postcricoid region, Aryepiglottic } \\
\text { fold, Overlapping lesion, } \\
\text { Hypopharynx }\end{array}$ & $\begin{array}{l}\text { Median } \\
25 \text { (1 to } \\
90)\end{array}$ & $\begin{array}{l}\text { Median } \\
2(1 \text { to } \\
90)\end{array}$ \\
\hline $\begin{array}{l}\text { Imre } \\
{[19]}\end{array}$ & 101 & $\begin{array}{l}\text { Mean } \\
58.5(41 \\
\text { to } 79)\end{array}$ & $95 \%$ & $\begin{array}{l}\text { Surgery OR Surgery } \\
\text { with (RT OR CRT) }\end{array}$ & $\begin{array}{l}\text { Radical, } \\
\text { Modified } \\
\text { Radical, } \\
\text { Selective }\end{array}$ & $\begin{array}{l}\text { T1 to } \\
\text { T4 }\end{array}$ & $\begin{array}{l}\mathrm{N} 1, \mathrm{~N} 2 \mathrm{a} / \\
\mathrm{b} / \mathrm{c}\end{array}$ & Glottis, Supraglottis, Transglottis & $\begin{array}{l}\text { Mean } \\
41.8(18 \\
\text { to } 88)\end{array}$ & $\begin{array}{l}\text { Mean } \\
2.9(1 \\
\text { to } 15)\end{array}$ \\
\hline $\begin{array}{l}\text { Ryu } \\
{[16]}\end{array}$ & 71 & $\begin{array}{l}\text { Median } \\
65(35 \\
\text { to } 79)\end{array}$ & $93 \%$ & $\begin{array}{l}\text { Surgery OR Surgery } \\
\text { with (RT OR CRT) }\end{array}$ & $\begin{array}{l}\text { Bilateral, } \\
\text { Modified } \\
\text { Radical, } \\
\text { Radical, } \\
\text { Selective }\end{array}$ & $\begin{array}{l}\text { T1 to } \\
\text { T4 }\end{array}$ & $\begin{array}{l}\text { No to } \\
\text { N2 }\end{array}$ & Supraglottis, Glottis, Transglottis & $\begin{array}{l}\text { Median } \\
52(11 \text { to } \\
\text { 153), }\end{array}$ & $\begin{array}{l}\text { Median } \\
4(1 \text { to } \\
21)\end{array}$ \\
\hline $\begin{array}{l}\text { Wang } \\
{[28]}\end{array}$ & 1963 & NA & $78 \%$ & $\begin{array}{l}\text { Surgery OR } \\
\text { Surgery with RT }\end{array}$ & NA & $\begin{array}{l}\mathrm{T} 1 \text { to } \\
\mathrm{T} 4 \mathrm{a} / \\
\mathrm{b}, \mathrm{Tx}\end{array}$ & $\begin{array}{l}\text { N1 to } \\
\text { N3 }\end{array}$ & $\begin{array}{l}\text { Glottis, Supraglottis, Subglottis, } \\
\text { Laryngeal cartilage, Overlapping } \\
\text { lesion, Larynx }\end{array}$ & $\begin{array}{l}\text { Median } \\
28 \text { (1 to } \\
90)\end{array}$ & $\begin{array}{l}\text { Median } \\
2(1 \text { to } \\
90)\end{array}$ \\
\hline $\begin{array}{l}\text { Künzel } \\
{[20]}\end{array}$ & 202 & $\begin{array}{l}\text { Median } \\
59(36 \\
\text { to } 86)\end{array}$ & $93.1 \%$ & $\begin{array}{l}\text { Surgery OR Surgery } \\
\text { with (RT OR CRT) }\end{array}$ & $\begin{array}{l}\text { Unilateral or } \\
\text { bilateral } \\
\text { modified } \\
\text { radical }\end{array}$ & $\begin{array}{l}\text { T1 to } \\
\text { T4 }\end{array}$ & $\begin{array}{l}\mathrm{N} 1, \mathrm{~N} 2 \mathrm{a} / \\
\mathrm{b} / \mathrm{c}\end{array}$ & $\begin{array}{l}\text { Glottic,Supraglottic,Unspecified } \\
\text { site of origin within the larynx }\end{array}$ & $\begin{array}{l}\text { Median } \\
27 \text { (10 to } \\
88)\end{array}$ & $\begin{array}{l}\text { Median } \\
2(1 \text { to } \\
19)\end{array}$ \\
\hline $\begin{array}{l}\text { Choi } \\
{[12]}\end{array}$ & 141 & $\begin{array}{l}\text { Median } \\
65(33 \\
\text { to } 78)\end{array}$ & $93.6 \%$ & $\begin{array}{l}\text { Surgery OR Surgery } \\
\text { with (RT OR CRT) }\end{array}$ & $\begin{array}{l}\text { Radical, } \\
\text { Selective }\end{array}$ & $\begin{array}{l}\text { T1 to } \\
\text { T5 }\end{array}$ & $\begin{array}{l}\text { N1 to } \\
\text { N3 }\end{array}$ & Larynx, Hypopharynx & $\begin{array}{l}\text { Median } \\
60(11 \text { to } \\
161)\end{array}$ & $\begin{array}{l}\text { Median } \\
1 \text { (0 to } \\
21)\end{array}$ \\
\hline $\begin{array}{l}\text { Grasl } \\
{[18]}\end{array}$ & 79 & $\begin{array}{l}\text { Median } \\
60(41.6 \\
\text { to } 83)\end{array}$ & $88.6 \%$ & $\begin{array}{l}\text { Surgery OR Surgery } \\
\text { with (RT OR CRT/IRT) }\end{array}$ & $\begin{array}{l}\text { Radical, } \\
\text { Modified } \\
\text { Radical, } \\
\text { Selective }\end{array}$ & $\begin{array}{l}\text { T1 to } \\
\text { T4 }\end{array}$ & $\begin{array}{l}\text { No, N1, } \\
\text { N2a/b/c, } \\
\text { N3a/b/c }\end{array}$ & Larynx, Hypopharynx & $\begin{array}{l}\text { Median } \pm \\
\text { SD } \\
48.0 \pm \\
23.8\end{array}$ & NA \\
\hline
\end{tabular}

NA Not available, RT Radiotherapy, CT Chemotherapy, CRT Chemoradiotherapy, IRT Radio-immune therapy, LNY Lymph node yield, PN+ Positive lymph node number

with short OS in Asian (HR 2.03, 95\%CI 1.58 to 2.61, $\mathrm{I}^{2}=2.6 \%$ ), European (HR 2.83, 95\%CI 1.67 to $4.79, \mathrm{I}^{2}=$ $0.0 \%$ ) and American (HR 1.35, 95\%CI 1.19 to $1.52, \mathrm{I}^{2}=$ $0.0 \%)$. Furthermore, the subgroup meta-analysis results based on quality scores of included studies also showed that a high LNR suggested poor survival, and the pooled HR values of subgroups with quality scores $>5$ were 2.36 (95\%CI, 1.57 to 3.54 ) for OS and 2.35 (95\%CI, 1.70 to 3.25$)$ for DSS. In addition, the subgroup analysis for laryngeal and hypopharyngeal cancers showed that 
Table 3 Quality assessment of eligible studies

\begin{tabular}{|c|c|c|c|c|c|c|c|c|c|}
\hline Study & $\begin{array}{l}\text { Inclusion and } \\
\text { exclusion criteria }\end{array}$ & $\begin{array}{l}\text { Prospective/ } \\
\text { Retrospective }\end{array}$ & $\begin{array}{l}\text { Patient } \\
\text { characteristics }\end{array}$ & $\begin{array}{l}\text { Tumor } \\
\text { characteristics }\end{array}$ & $\begin{array}{l}\text { LNR } \\
\text { measurements }\end{array}$ & Endpoint & $\begin{array}{l}\text { Follow- } \\
\text { up } \\
\text { period }\end{array}$ & $\begin{array}{l}\text { Patients unavailable for } \\
\text { statistical analysis }\end{array}$ & $\begin{array}{l}\text { Quality } \\
\text { scale }\end{array}$ \\
\hline $\begin{array}{l}\text { Choi } \\
2019 \text { [12] }\end{array}$ & 1 & 1 & 1 & 1 & 0 & 0 & 1 & 0 & 5 \\
\hline $\begin{array}{l}\text { Ye } 2018 \\
{[22]}\end{array}$ & 1 & 1 & 1 & 1 & 0 & 1 & 1 & 1 & 7 \\
\hline $\begin{array}{l}\text { Lo } 2017 \\
{[15]}\end{array}$ & 1 & 1 & 1 & 1 & 0 & 0 & 1 & 0 & 5 \\
\hline $\begin{array}{l}\text { Suzuki } \\
2016[21]\end{array}$ & 1 & 1 & 1 & 1 & 0 & 1 & 1 & 0 & 6 \\
\hline $\begin{array}{l}\text { Imre } \\
2016 \text { [19] }\end{array}$ & 1 & 1 & 1 & 1 & 0 & 1 & 1 & 0 & 6 \\
\hline $\begin{array}{l}\text { Ryu } 2015 \\
{[16]}\end{array}$ & 1 & 1 & 1 & 1 & 1 & 1 & 1 & 0 & 7 \\
\hline $\begin{array}{l}\text { Kunzel } \\
2015[20]\end{array}$ & 1 & 1 & 1 & 1 & 1 & 1 & 1 & 0 & 7 \\
\hline $\begin{array}{l}\text { Joo } 2015 \\
{[14]}\end{array}$ & 1 & 1 & 1 & 1 & 1 & 0 & 1 & 0 & 6 \\
\hline $\begin{array}{l}\text { Hua } \\
2015 \text { [13] }\end{array}$ & 0 & 1 & 1 & 1 & 0 & 0 & 1 & 0 & 4 \\
\hline $\begin{array}{l}\text { Wang } \\
2014[28]\end{array}$ & 1 & 1 & 1 & 1 & 0 & 0 & 0 & 0 & 4 \\
\hline $\begin{array}{l}\text { Yu } 2013 \\
{[29]}\end{array}$ & 1 & 1 & 1 & 1 & 0 & 0 & 1 & 0 & 5 \\
\hline $\begin{array}{l}\text { Wang } \\
2013 \text { [27] }\end{array}$ & 1 & 1 & 1 & 1 & 0 & 0 & 1 & 1 & 6 \\
\hline $\begin{array}{l}\text { Grasl } \\
2019 \text { [18] }\end{array}$ & 1 & 1 & 1 & 1 & 0 & 1 & 1 & 0 & 6 \\
\hline
\end{tabular}

LNR Lymph node ratio

increased LNR was associated with poor prognosis regardless of the tumor sites (Table 4).

\section{Publication bias}

The Funnel plots of studies that reported OS $(p<0.01)$ and DSS $(p<0.01)$ in the meta-analysis were asymmetric. Moreover, quantitative evaluation results achieved by the Begg's and Egger's tests indicated that the publication bias was statistically significant. Five additional studies in OS (Fig. S1) and six in DSS (Fig. S2) that may be missed were filled with using the trim and fill method. After adjustment, the pooled HR value was 1.49 (95\%CI, 1.18 to 1.88$)$ for OS and 1.66 (95\%CI, 1.33 to 2.07) DSS, indicating that the existing publication bias did not affect the final results.

\section{Sensitivity analysis}

To ensure the robustness of the pooled adjusted HR values, we ruled out the adjusted HR value of the study of $\mathrm{Yu}$ et al. [29], which included population having received pre-operative radiation. We achieved the similar results, that is, an increased LNR value resulted in poor
OS (HR: 1.89 ; 95\%CI, 1.45 to 2.47 ) and DSS (HR: 2.07 ; 95\% CI, 1.60 to 2.68$)$.

\section{Discussion}

Nearly 170,000 new cases of laryngeal cancer occur worldwide each year, and more than 90,000 people die of it [30]. The incidence of hypopharyngeal cancer is about a quarter of that of laryngeal cancer.

Early studies found that the incidence of positive cervical lymph node dissection of LSCC was $32.9 \%$, and the incidence of locally advanced tumors was $70.8 \%$ [31]. Cervical metastases of HPSCC usually occur more frequently in HPSCC than in LSCC, and 80\% HPSCC patients undergoing initial surgery and neck dissection suffer from cervical metastases [14, 21]. Local lymph node metastasis could increase tumor recurrence and mortality. Thus, a staging system is needed to stratify patients, and then possibly determine which patients are more suitable for aggressive treatment.

The current TNM staging was subdivided into refined grades, which allocated one positive lymph node $\leq 3 \mathrm{~cm}$ with ENE to the N2a category, and one positive Lymph node $>3 \mathrm{~cm}$ with ENE or any two or more positive 


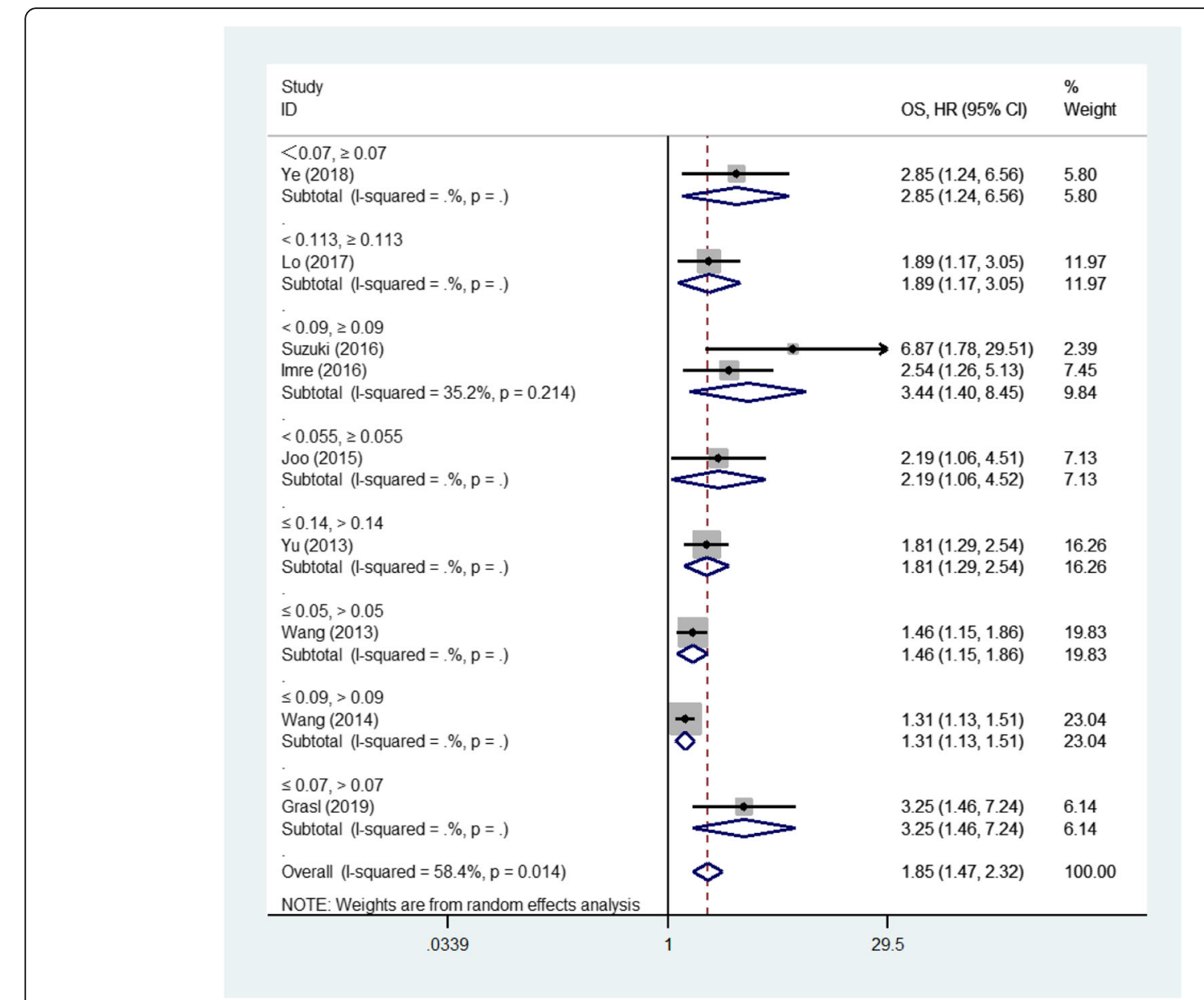

Fig. 2 Forest plot of the meta-analysis regarding the overall survival (OS). Forest plot of the meta-analysis using the random-effect model in patients with LHSCC regarding OS. OS: Overall survival; HR: Hazard ratio; LHSCC: Laryngeal and hypopharyngeal squamous cell carcinoma

lymph nodes with ENE to the N3b category [2]. However, the $\mathrm{N}$ staging does not involve the metastatic lymph node burden as an important prognostic factor in LHSCC [32], so it may underestimate the cumulative effect of burden escalation of metastatic lymph nodes [32].

Since metastatic lymph node burden is one of the most important prognostic indicators of head and neck cancers [4, 32-34], and can increase the recurrence rate and mortality [33, 35], a variety of features of lymph nodes as prognostic indicators for head and neck cancer, were investigated thoroughly. As for LHSCC, extracapsular spread (ECS) [35], number of positive lymph nodes $[12,13,32]$, and lymph node yield $[18,36,37]$ were reported. In recent years, several studies suggested that LNR or LND was an independent risk factor for patients with head and neck cancers [4, 33, 37-39], including LHSCC [13-16, 18, 19, 21, 22], while some other studies found no significant relationship between survival and the LNR or LND for LHSCC $[12,40]$. As a result, there is no consensus on whether LNR as a significant prognostic factor complements the TNM staging system.
The systematic review and meta-analysis suggested that high LNR values reflected significantly short OS, DSS, and DFS in LHSCC patients undergoing surgery with or without neoadjuvant therapy. The subgroup analysis by region or tumor site also proved that a LNR value was related to poor survival. Besides, the analysis of only high-quality studies obtained similar results. Although publication bias might exist in the studies included, the results adjusted by the trim and fill method demonstrated the bias made no difference to the final results. We found similar results via the sensitivity analysis.

Some studies have found that the positive lymph nodes is also an important prognostic indicator in patients suffering from LHSCC, and more positive lymph nodes predicted an increased mortality rate [12, 32]. Since the number of positive lymph nodes produced is influenced by the technique of neck dissection selected, the low value may mislead practitioners into making the wrong diagnosis of the actual disease [11]. Besides, some believed that positive lymph nodes might be superior to 


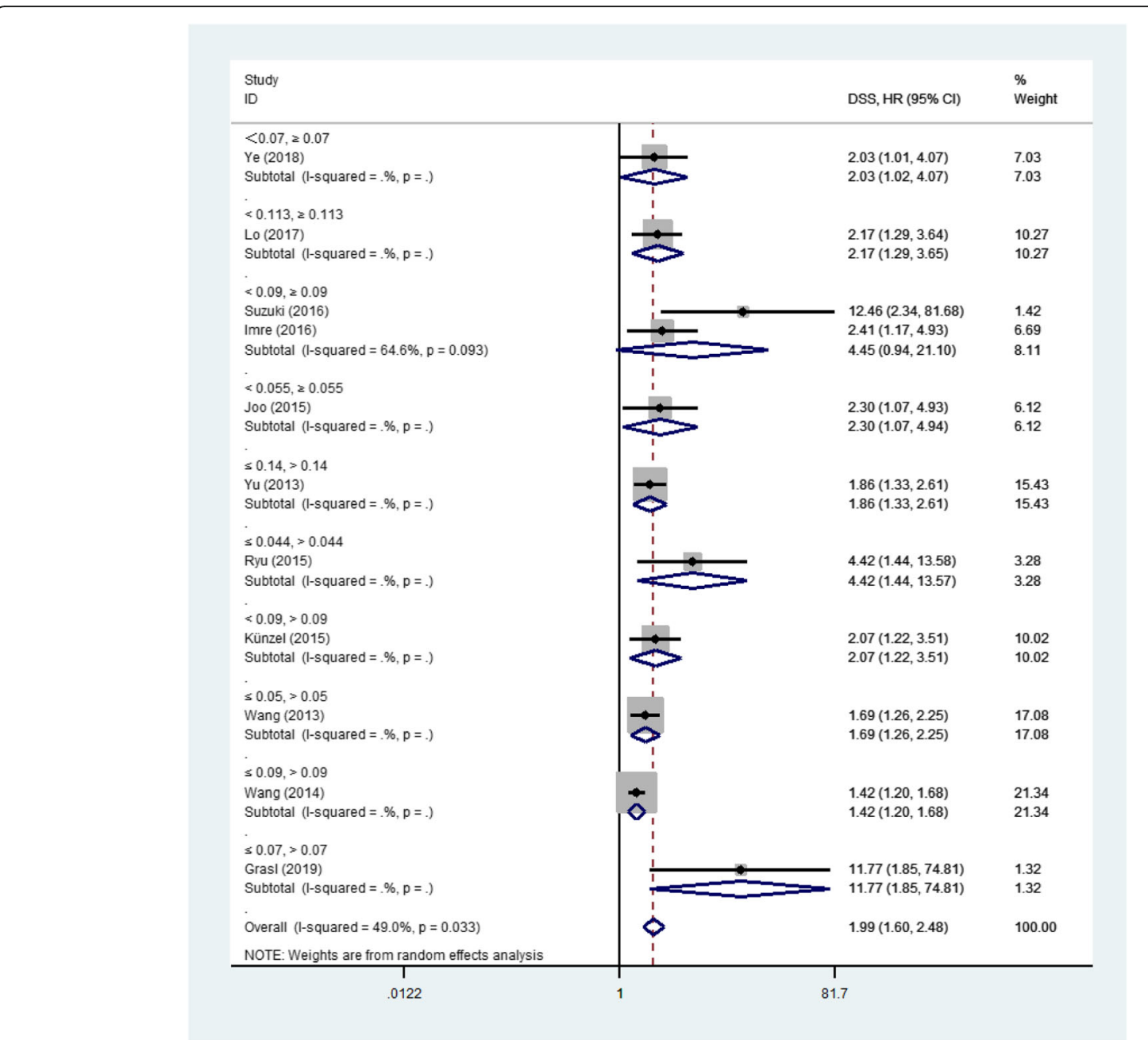

Fig. 3 Forest plot of the meta-analysis regarding the disease-specific survival (DSS). Forest plot of the meta-analysis using the random-effect model in patients with LHSCC regarding DSS. DSS: Disease-specific survival; HR: Hazard ratio; LHSCC: Laryngeal and hypopharyngeal squamous cell carcinoma

LNR as a significant predictor for head and neck cancers, such as LHSCC [3]. In the multicenter study based on the SEER database, data on the type of neck dissection, the protocol of pathologic review of dissection, recurrence rate, the adjuvant chemotherapy, and ECS were unavailable. Similar limitations also existed in two studies $[27,28]$ included in this meta-analysis.

Radical, modified radical, and selective neck dissection are recommended for the removal of the tumors [1]. Previous studies considered lymph nodes yield might be associated with the survival of LHSCC [36, 41], but the lymph node yield is greatly influenced by the type of cervical lymph node dissection, and there is no universally accepted threshold up to now. Besides, lymph node hypertrophy occurring differently among individuals makes the lymph nodes yield less reliable [11]. As a result, lymph node yield may not be a good indicator of the impact of positive lymph nodes on survival.

LNR is a better prognostic measurement, for it makes a combination of information on the burden of regionally metastatic disease and type of neck dissection, so it integrates the advantages of these two parameters while bypassing their disadvantages.

In this review, the cutoff values were calculated through different methods, and the lowest significant LNR value was 0.044 , which is close to the lowest value of 0.025 in oral cavity cancer reported by Huang et al [11]

To the best of our knowledge, this article is the first one that conducts a meta-analysis by taking LNR as a significant prognostic indicator for LHSCC. The pooled results suggested that LNR was an independent 


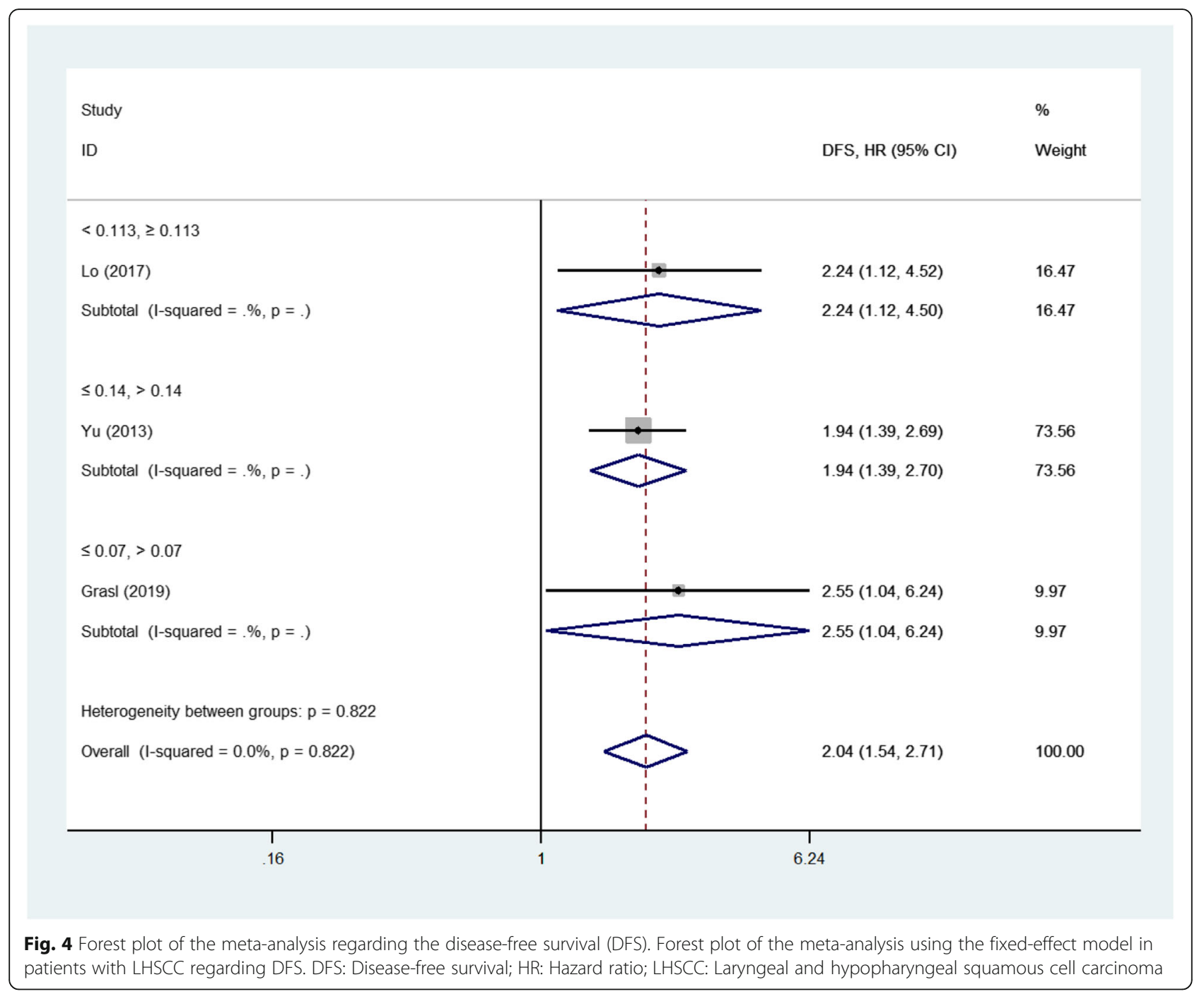

prognosticator of survival in patients with LHSCC, and might be able to group patients into different levels through the significance of adjuvant therapy.

There are some inherent limitations to this study. Firstly, the data of most studies were collected retrospectively. Thus, some important clinical information generally had low quality, which might render the survival results limited, such as ECS, adjuvant chemotherapy protocol and patient adherence. Additionally, the acquisition of clinicopathologic information might not be acceptable. On the other hand, long-term follow-up information was available for retrospective studies. Secondly, some studies did not adjust for all the significant factors in the multivariate analysis, such as whether to receive adjuvant chemotherapy. Moreover, most eligible studies identified LNR cutoff points through the analysis of time-dependent receiver operating characteristic curves which was based on the so-called optimal cutpoint and might overestimate the effect of prognosis [42]. Thirdly, one study [12] included in the review that found LNR was not associated with survival did not report the negative adjusted HR values, and all studies included in the quantitative synthesis yielded positive results. In order to make the results more robust and reliable, we conducted a sensitivity analysis that synthesized high-quality studies and obtained similar results.

Table 4 Subgroup analysis by tumor sites

\begin{tabular}{llll}
\hline Sites & OS & DSS & DFS \\
\hline Hypopharyngeal cancer & HR 1.87,95\%Cl 1.37 to 2.56,6 studies & HR 1.89,95\%Cl 1.47 to 2.42, 7 studies & HR 1.99, 95\%Cl 1.48 to 2.68, 3 studies \\
Laryngeal cancer & HR 1.74 95\%Cl (1.05 to 2.88), 2 studies & HR 2.11,95\%Cl (1.34 to 3.34), 3 studies & NA
\end{tabular}


Fourthly, we grouped all LHSCC to review, which may bias the accuracy of the results. But two studies $[12,18]$ exploring the prognostic value of LNR in LHSCC demonstrated that tumor site, whether laryngeal or hypopharyngeal, had no significant on OS, DSS and DFS. Besides, we analyzed the LSCC data separately from the HPSCC, and the subgroup analysis results was similar with the overall. Finally, the sample size of eligible studies was small, resulting in publication bias because positive results from small sample size studies are more likely to be published.

\section{Conclusion}

This review indicates that increased high LNR values are related to poor OS, DSS, and DFS in patients with LHSCC undergoing surgery with or without neoadjuvant therapy. Nevertheless, if LNR can serve as a supplement to TNM staging and improve the accuracy of tumor staging and the cutoff values we have proposed are valid, more large samples and high-quality studies are needed to verify its reliability in the future.

\section{Supplementary information}

Supplementary information accompanies this paper at https://doi.org/10. 1186/s40463-020-00421-w.

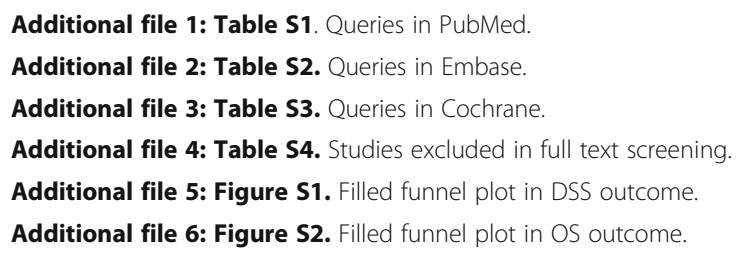

\section{Acknowledgements}

Not applicable.

\section{Authors' contributions}

$J$ contributed to concepts, design of the work and writing the manuscript; $\mathrm{AA} 1$ and $\mathrm{SH}$ were responsible for the literature retrieval, literature screening and data extraction and equal contribute to this work; $Y Z$ and $G M$ are in charge of data analysis and interpretation; AA2 and MY double checked the manuscript, figures and tables and ensured the accuracy of the results. All authors read and approved the final manuscript.

\section{Funding}

There is no funding or commercial support for the study.

\section{Availability of data and materials}

Not applicable.

\section{Ethics approval and consent to participate}

Not applicable.

\section{Consent for publication}

Not applicable.

\section{Competing interests}

The authors declare that they have no competing interests.

\section{Author details}

${ }^{1}$ Department of Otorhinolaryngology Head and Neck Surgery, People's Hospital of Xinjiang Uygur Autonomous Region, 91 Tianchi Road, Tianshan, Ürümqi, Xinjiang 830001, China. ${ }^{2}$ Department of Otolaryngology-Head and Neck Surgery, Beijing Tongren Hospital, Capital Medical University, Beijing, China. ${ }^{3}$ Department of Otorhinolaryngology, China-Japan Friendship Hospital, Beijing, China. ${ }^{4}$ Department of Neurosurgery, China-Japan Friendship Hospital, No. 2, Yinghua East Street, Chaoyang District, Beijing 100029, China.

Received: 13 December 2019 Accepted: 22 April 2020

Published online: 29 May 2020

\section{References}

1. Colevas AD, Yom SS, Pfister DG, et al. NCCN guidelines insights: head and neck cancers, version 1.2018. J Natl Compr Cancer Netw. 2018;16(5):479-90. https://doi.org/10.6004/jnccn.2018.0026.

2. Cancer AJ. Co. AJCC Cancer Staging Manual. 8th ed. New York: Springer International Publishing; 2017.

3. Roberts TJ, Colevas AD, Hara W, et al. Number of positive nodes is superior to the lymph node ratio and American joint committee on Cancer $\mathrm{N}$ staging for the prognosis of surgically treated head and neck squamous cell carcinomas. Cancer. 2016;122(9):1388-97. https://doi.org/10.1002/cncr.29932.

4. Chen CC, Lin JC, Chen KW. Lymph node ratio as a prognostic factor in head and neck cancer patients. Radiat Oncol. 2015;10:181. https://doi.org/10.1186/ s13014-015-0490-9.

5. Shao Y, Geng Y, Gu W, et al. Assessment of lymph node ratio to replace the $\mathrm{pN}$ categories system of classification of the TNM system in esophageal squamous cell carcinoma. J Thorac Oncol. 2016;11(10):1774-84. https://doi. org/10.1016/j.jtho.2016.06.019.

6. Parnaby CN, Scott NW, Ramsay G, et al. Prognostic value of lymph node ratio and extramural vascular invasion on survival for patients undergoing curative colon cancer resection. Br J Cancer. 2015;113(2):212-9. https://doi. org/10.1038/bjc.2015.211.

7. Ceelen W, Van Nieuwenhove Y, Pattyn P. Prognostic value of the lymph node ratio in stage III colorectal cancer: a systematic review. Ann Surg Oncol. 2010;17(11):2847-55. https://doi.org/10.1245/s10434-010-1158-1.

8. Zhou Y, Zhang J, Cao S, et al. The evaluation of metastatic lymph node ratio staging system in gastric cancer. Gastric Cancer. 2013;16(3):309-17. https://doi.org/10.1007/s10120-012-0190-1.

9. Kim SI, Cho SH, Lee JS, et al. Clinical relevance of lymph node ratio in breast cancer patients with one to three positive lymph nodes. Br J Cancer. 2013; 109(5):1165-71. https://doi.org/10.1038/bjc.2013.465.

10. Cheraghlou S, Otremba M, Kuo Yu P, et al. Prognostic value of lymph node yield and density in head and neck malignancies. Otolaryngol Head Neck Surg. 2018;158(6):1016-23. https://doi.org/10.1177/0194599818756830.

11. Li KY, Choi WS. Lymph node ratio as prognostic variable in oral squamous cell carcinomas: systematic review and meta-analysis. Oral Oncol. 2019;89: 133-43. https://doi.org/10.1016/j.oraloncology.

12. Choi $Y$, Bin-Manie $M$, Roh $J$, et al. Metastatic lymph node burden predictive of survival in patients undergoing primary surgery for laryngeal and hypopharyngeal cancer. J Cancer Res Clin Oncol. 2019;145(10):2565-72. https://doi.org/10.1007/s00432-019-02990-4.

13. Hua YH, Hu QY, Piao YF, et al. Effect of number and ratio of positive lymph nodes in hypopharyngeal cancer. Head Neck. 2015;37(1):111-6. https://doi. org/10.1002/hed.23574.

14. Joo YH, Cho KJ, Kim SY, et al. Prognostic significance of lymph node density in patients with Hypopharyngeal squamous cell carcinoma. Ann Surg Oncol. 2015;22(Suppl 3):S1014-9. https://doi.org/10.1245/s10434-015-4726-6.

15. Lo WC, Wu CT, Wang CP, et al. Lymph node ratio predicts recurrence and survival for patients with Resectable stage 4 Hypopharyngeal Cancer. Ann Surg Oncol. 2017;24(6):1707-13. https://doi.org/10.1245/s10434-017-5770-1.

16. Ryu IS, Roh JL, Cho KJ, et al. Lymph node density as an independent predictor of cancer-specific mortality in patients with lymph node-positive laryngeal squamous cell carcinoma after laryngectomy. Head Neck. 2015; 37(9):1319-25. https://doi.org/10.1002/hed.23750.

17. Liberati A, Altman DG, Tetzlaff J, et al. The PRISMA statement for reporting systematic reviews and meta-analyses of studies that evaluate healthcare interventions: explanation and elaboration. BMJ. 2009;339:b2700. https://doi. org/10.1136/bmj.b2700.

18. Grasl S, Janik S, Parzefall T, et al. Lymph node ratio as a prognostic marker in advanced laryngeal and hypopharyngeal carcinoma after primary total 
laryngopharyngectomy. Clin Otolaryngol. 2019. https://doi.org/10.1111/coa. 13468.

19. Imre A, Pinar E, Dincer E, et al. Lymph node density in node-positive laryngeal carcinoma: analysis of prognostic value for survival. Otolaryngol Head Neck Surg. 2016;155(5):797-804.

20. Kunzel J, Mantsopoulos K, Psychogios G, et al. Lymph node ratio is of limited value for the decision-making process in the treatment of patients with laryngeal cancer. Eur Arch Otorhinolaryngol. 2015;272(2):453-61. https://doi.org/10.1007/s00405-014-2997-3.

21. Suzuki H, Matoba T, Hanai $N$, et al. Lymph node ratio predicts survival in hypopharyngeal cancer with positive lymph node metastasis. Eur Arch Otorhinolaryngol. 2016;273(12):4595-600.

22. Ye LL, Rao J, Fan XW, et al. Impact of tumor dimensions and lymph node density on the survival of patients with hypopharyngeal squamous cell carcinoma. Cancer Manag Res. 2018;10:4679-88. https://doi.org/10.2147/ CMAR.S178750.

23. $\mathrm{Ku} \mathrm{JH}$, Kang M, Kim HS, et al. Lymph node density as a prognostic variable in node-positive bladder cancer: a meta-analysis. BMC Cancer. 2015;15:447. https://doi.org/10.1186/s12885-015-1448-x.

24. Altman DG, McShane LM, Sauerbrei W, et al. Reporting recommendations for tumor marker prognostic studies (REMARK): explanation and elaboration. PLoS Med. 2012;9(5):e1001216. https://doi.org/10.1371/journal.pmed. 1001216.

25. McShane LM, Altman DG, Sauerbrei W, et al. REporting recommendations for tumour MARKer prognostic studies (REMARK). Br J Cancer. 2005;93(4): 387-91. https://doi.org/10.1038/sj.bjc.6602678.

26. Higgins JP, Thompson SG, Deeks JJ, et al. Measuring inconsistency in meta-analyses. BMJ. 2003;327(7414):557-60. https://doi.org/10.1136/bmj.327.7414.557.

27. Wang $\mathrm{YL}$, Feng $\mathrm{SH}$, Zhu J, et al. Impact of lymph node ratio on the survival of patients with Hypopharyngeal squamous cell carcinoma: a populationbased analysis. PLoS One. 2013;8(2):e56613. https://doi.org/10.1371/journal. pone.0056613.

28. Wang YL, Li DS, Wang Y, et al. Lymph node ratio for postoperative staging of laryngeal squamous cell carcinoma with lymph node metastasis. PLoS One. 2014;9(1):e87037. https://doi.org/10.1371/journal.pone.0087037.

29. Yu Y, Wang $X L, X u Z G$, et al. Prognostic value of lymph node ratio in hypopharyngeal squamous cell carcinoma after chemoradiotherapy. Chin Med J. 2013;126(21):4139-44. https://doi.org/10.3760/cmaj.jissn.0366-6999. 20131992.

30. Bray F, Ferlay J, Soerjomataram I, et al. Global cancer statistics 2018: GLOBOCAN estimates of incidence and mortality worldwide for 36 cancers in 185 countries. CA Cancer J Clin. 2018;68(6):394-424. https://doi.org/10. 3322/caac.21492.

31. Tomik J, Składzien J, Modrzejewski M. Evaluation of cervical lymph node metastasis of 1400 patients with cancer of the larynx. Auris Nasus Larynx. 2001;28(3):233-40. https://doi.org/10.1016/s0385-8146(00)00116-4.

32. Ho AS, Kim S, Tighiouart M, et al. Association of Quantitative Metastatic Lymph Node Burden with Survival in Hypopharyngeal and laryngeal Cancer. JAMA Oncol. 2018;4(7):985-9. https://doi.org/10.1001/jamaoncol.2017.3852.

33. Reinisch $\mathrm{S}$, Kruse A, Bredell $M$, et al. Is lymph-node ratio a superior predictor than lymph node status for recurrence-free and overall survival in patients with head and neck squamous cell carcinoma? Ann Surg Oncol. 2014;21(6): 1912-8. https://doi.org/10.1245/s10434-014-3634-5.

34. Trifiletti DM, Smith A, Mitra N, et al. Beyond positive margins and Extracapsular extension: evaluating the utilization and clinical impact of postoperative Chemoradiotherapy in resected locally advanced head and neck Cancer. J Clin Oncol. 2017;35(14):1550-60. https://doi.org/10.1200/jco. 2016.68.2336.

35. Fletcher KT, Gal TJ, Ebelhar AJ, et al. Prognostic indicators and survival in salvage surgery for laryngeal cancer. Head Neck. 2017;39(10):2021-6. https:// doi.org/10.1002/hed.24860

36. Bottcher A, Dommerich S, Sander S, et al. Nodal yield of neck dissections and influence on outcome in laryngectomized patients. Eur Arch Otorhinolaryngol. 2016;273(10):3321-9. https://doi.org/10.1007/s00405-0163928-2.

37. Sano D, Yabuki K, Takahashi H, et al. Lymph node ratio as a prognostic factor for survival in patients with head and neck squamous cell carcinoma. Auris Nasus Larynx. 2018;45(4):846-53. https://doi.org/10.1016/j.anl.2017.11.015.

38. Yildiz MM, Petersen I, Eigendorff $E$, et al. Which is the most suitable lymph node predictor for overall survival after primary surgery of head and neck cancer: $\mathrm{pN}$, the number or the ratio of positive lymph nodes, or log odds? J
Cancer Res Clin Oncol. 2016;142(4):885-93. https://doi.org/10.1007/s00432015-2104-1.

39. Dequanter D, Zouaoui Boudjeltia K, Shahla M, et al. Prognostic value of lymph node ratio for locoregional failure in patients with advanced head and neck cancers. Minerva Stomatol. 2016;65(1):39-42.

40. Cayonu M, Tuna EU, Acar A, et al. Lymph node yield and lymph node density for elective level II-IV neck dissections in laryngeal squamous cell carcinoma patients. Eur Arch Otorhinolaryngol. 2019;276(10):2923-7. https:// doi.org/10.1007/s00405-019-05560-z.

41. Divi V, Chen MM, Nussenbaum B, et al. Lymph node count from neck dissection predicts mortality in head and neck cancer. J Clin Oncol. 2016; 34(32):3892-7. https://doi.org/10.1200/JCO.2016.67.3863.

42. Holländer N, Sauerbrei W, Schumacher M. Confidence intervals for the effect of a prognostic factor after selection of an 'optimal' cutpoint. Stat Med. 2004;23(11):1701-13. https://doi.org/10.1002/sim.1611.

\section{Publisher's Note}

Springer Nature remains neutral with regard to jurisdictional claims in published maps and institutional affiliations.

\section{Ready to submit your research? Choose BMC and benefit from:}

- fast, convenient online submission

- thorough peer review by experienced researchers in your field

- rapid publication on acceptance

- support for research data, including large and complex data types

- gold Open Access which fosters wider collaboration and increased citations

- maximum visibility for your research: over $100 \mathrm{M}$ website views per year

At BMC, research is always in progress.

Learn more biomedcentral.com/submissions 